E-JURNAL EKONOMI DAN BISNIS UNIVERSITAS UDAYANA
Available online at https://ojs.unud.ac.id/index.php/EEB/index
Vol. 10 No. 11, November 2021, pages: $967-980$
e-ISSN: 2337-3067

\title{
PENGARUH PENGETAHUAN PERPAJAKAN, KUALITAS PELAYANAN, DAN KESADARAN WAJIB PAJAK TERHADAP KEPATUHAN WAJIB PAJAK UMKM SURABAYA
}

\section{Chandra Pitaloka Puspodewanti ${ }^{1}$ Susanti ${ }^{2}$}

\begin{tabular}{l}
\hline \hline Article history: \\
\hline Submitted: 2 Juni2021 \\
Revised: 23 Juni2021 \\
Accepted: 30 Juni2021 \\
\hline
\end{tabular}

\section{Keywords:}

Tax Knowladge;

Service Quality;

Taxpayer Awarness;

Taxpayer Compliance.

\section{Kata Kunci:}

Pengetahuan Perpajakan;

Kualita s Pelayanan;

Kesa daran Wajib Pajak;

Kepatuhan Wajib Pajak.

\section{Koresponding:}

Fakultas Ekonomidan Bisnis, Universitas Negeri Surabaya,

Jawa Timur, Indonesia

Email: chandra.

17080304055@mhs.unesa.ac.id

\section{Abstract}

Compliance with paying taxes is indispensable, because the tax sector is the largest revenue in the country. This re se arch aims to see how the influence of tax knowledge, service quality and taxpayer awareness on taxpayer compliance of MSME actors in Surabaya. MSME actors, especially those who have been registered as taxpayers at KPP Pratama Surabaya Wonocolo, are the subjects used in this research. By using multiple linear regression techniques and SPPS program assistance, the resultsobtained that taxpayer compliance is influenced by tax knowledge, service quality and taxpayer awareness together. Partially taxation knowledge has a significant effect on taxpayer compliance, service qualitydoes not have a significant effect on taxpayer compliance, and taxpayer awareness has a significant effecton taxpayer compliance.

Abstrak
Kepatuhan membayar pajak merupakan halyang sangat diperlukan,
sebab sektor perpajakan merupakan penerimaan terbesar di Ne ga ra. Riset
ini bertujuan untuk melihat bagaimana pengaruh antara pengetahuan
perpajakan, kualitas pelayanan dan kesa daran wajib pajak terhadap
kepatuhan wajib pajak pelaku UMKM di Surabaya. Pelaku UMKM
khususnya yang telah terdaftar seba gai wajib pajak di KPP Pratama
Surabaya Wonocolo merupakan subjekyang digu nakan dalam riset ini.
Dengan menggunakan teknik regresi linier berganda dan bantuan pro gram
SPPS, diperoleh hasil bahwa kepatuhan wajib pajak dipengaruhi oleh
pengetahuan perpajakan, kualitas pelayanan serta kesadaran wajib pajak
secara bersama sama. Secara parsial pengetahuan perpajakan memberikan
pengaruh secara signifikan pada kepatuhan wajib pajak, kualitas pelayanan
tidak memberipengaruh yang signifikan pada kepatuhan wajib pajak, serta
kesadaran wajib pajak memberikan pengaruh yang signifikan pada
kepatuhan wajib pajak.

\section{Abstrak} sebab sektor perpajakan merupakan penerimaan terbesar di Ne ga ra. Riset ini bertujuan untuk melihat bagaimana pengaruh antara pengetahuan perpajakan, kualitas pelayanan dan kesadaran wajib pajak terhadap kepatuhan wajib pajak pelaku UMKM di Surabaya. Pelaku UMKM khususnya yang telah terdaftar sebagai wajib pajak di KPP Pratama Surabaya Wonocolo merupakan subjek y ang digu nakan dala m riset ini. Dengan menggunakan teknik regresi linier berga nda dan bantuan pro gram SPPS, diperoleh hasil bahwa kepatuhan wajib pajak dipengaruhi oleh pengetahuan perpajakan, kualitas pelayanan serta kesadaran wajib pajak seca ra bersama sama. Secara parsial pengetahuan perpajakan memberikan penga ruh secara signifikan pada kepatuhan wajib pajak, kualitas pelaya nan tidak memberi pen garuh yang signifikan pada kepatuhan wajib pajak, serta kepatuhan wajib pajak.

Fa kultas Ekonomidan Bisnis, Universitas Negeri Surabaya, Jawa Timur, Indonesia ${ }^{2}$

Email: susanti@unesa.ac.id 


\section{PENDAHULUAN}

Pembangunan Negara pada dasarnya merupakan suatu kewajiban yang secara bersama-sama harus dilaksanakan baik oleh pemerintah maupun masyarakat. Pembangunan Negara yang baik ialah meningkatnya fasilitas-fasilitas umum yang manfaatnya dapat dirasakan oleh masyarakat secara merata. Untuk dapat melaksanakan pembangunan, maka diperlukan adanya pembiayaan. Pembiay aan untuk pembangunan Negara salah satunya bersumber dari penerimaan pajak. Dalam keberlangsungan sebuah Negara, pajak ialah salah satu aspek yang paling penting, sebab penerimaan terbesar Negara bersumber dari sektor perpajakan. Dapat dikatakan bahwa pajak adalah hal penting dalam menunjang kehidupan suatu Negara. Tanpa adanya pajak, pembangunan Negara tidak dapat terlaksana dengan baik. Dengan demikian, kepatuhan wajib pajak agar bertanggung jawab untuk menjalankan seluruh kewajibannya di bidang perpajakan sangat diperlukan. Sehingga pembiayaan untuk pembangunan Negara tidak akan terhambat.

Undang-Undang No. 16 Tahun 2009 menjelaskan pajak ialah kewajiban yang harus dilaksanakan oleh masyarakat baik itu orang pribadi maupun badan yang sifatnya adalah memaksa dengan berdasarkan undang-undang yang telah ditetapkan, namun imbalan dari membayar pajak tidak dapat diberikan secara langsung, melainkan pengelolaannya diatur oleh pemerintah sebagai usaha untuk memakmurkan kesejahteraan masyarakat secara merata. Berdasarkan definisi pajak tersebut dapat diketahui bahwa konsep pajak ialah penarikannya memaksa yang berdasarkan undang-undang serta imbalan tidak didapatkan secara langsung. Karena sifatnya yang memaksa namun imbalannya tidak didapat langsung, sehingga masih banyak wajib pajak yang menilai bahwa pembayaran pajak tidak teramat penting. Hal tersebut dibuktikan dengan target pajak yang telah ditentukan masih belum terpenuhi. Adapun besaran target dan realisasi penerimaan pajak yang diterima oleh Indonesia pada tahun 2017 hingga 2019 adalah sebagai berikut:

Tabel 1.

Data target dan realisasi penerimaan pajak 2017-2019

\begin{tabular}{llll}
\hline Tahun & Target & Realisasi & Prosentase \\
\hline 2017 & Rp 1.283 T & Rp 1.147 T & $89,4 \%$ \\
2018 & Rp 1.424 T & Rp 1.315,9T & $92 \%$ \\
2019 & RP 1.577,6 T & Rp 1.332,1 T & $84,4 \%$ \\
\hline
\end{tabular}

Sumber: Kemenku, 2021

Menurut Ester et al., (2017) kepatuhan wajib pajak yang masih rendah disebabkan karena ketidakpuasan terhadap pelayanan yang diberikan oleh petugas publik, pembangunan infrastruktur yang masih belum merata, serta masih banyaknya pejabat tinggi yang melakukan tindak korupsi. Kepatuhan wajib pajak menurut Fuadi \& Mangoting (2012) dipengaruhi oleh dua faktor. Pertama faktor internal, ialah faktor yang terdapat dari dalam diri seseorang, yang mana faktor tersebut akan menentukan sikapnya dalam melaksanakan kewajiban perpajakannya. Kedua faktor eksternal, merupakan faktor yang terdapat diluar diri individu tersebut, untuk mempengaruhinya pula dalam memutuskan sikapnya untuk melaksanakan tanggung jawab perpajakannya. Dalam penelitian Oktaviani \& Adellina (2016) berpendapat bahwa pengetahuan perpajakan, kesadaran pajak, serta kualitas pelayanan fiskus ialah beberapa contoh faktor yang dapat mempengaruhi tingkat kepatuhan wajib pajak. Penelitian oleh Siat \& Toly (2018) mendapatkan hasil bahwa, kesadaran wajib pajak,

Pengaruh Pengetahuan Perpajakan, Kualitas Pelayanan Dan Kesadaran Wajib Pajak Terhadap Kepatuhan Wajib PajakUMKM Surabaya, 
petugas pajak, hukum pajak, serta sikap rasional wajib pajak merupakan faktor yang memiliki pengaruh pada patuh wajib pajak untuk memenuhi kewajiban pajaknya. Adapun untuk dapat mengetahui tinggi maupun rendahnya kepatuhan wajib pajak menurut Rahayu yang dikemukakan kembali oleh Kusuma (2016) dapat diukur dengan beberapa indikator, antara lain kepatuhan untuk terdaftar sebagai wajib pajak, kepatuhan untuk menghitung pajak sesuai dengan kondisi dan membayar pajak terutang, kepatuhan untuk membayar tunggakan pajak, serta kepatuhan dalam menyetorkan kembali SPT.

Pengetahuan perpajakan yang dimaksud merupakan sebuah pemahaman terkait seluruh informasi serta hal-hal terkait perpajakan yang seharusnya dimiliki oleh seorang wajib wajib pajak, kemudian pengetahuan tersebut dapat diimplementasikan dalam memenuhi kewajiban perpajakannya. salah satu hal penting yang wajib dimiliki oleh wajib pajak agar tidak merasakan kesulitan saat melaksanakan kewajibannya di bidang perpajakan adalah pengetahuan pajak. Menurut Saputri (2019) di Indonesia masih terdapat banyak sekali wajib pajak belum memiliki pengetahuan serta belum memahami perpajakan dengan baik. Pengetahuan perpajakan ialah sebuah informasi yang harus diketahui oleh wajib pajak yang dapat berguna untuk mengambil keputusan, bertindak, serta menentukan sikap dalam melaksanakan kewajibannya dibidang perpajakan (Ester et al., 2017). Menurut Adi (2018) terdapat beberapa indikator untuk mengetahui tinggi rendahnya pengertahuan perpajakan yang dimiliki oleh seseorang. Antara lain menilai pengetahan tentang ketentuan umum serta tata cara perpajakan yang berlaku, pengetahuan tentang fungsi penarikan pajak, dan terakhir pengetahuan tentang sistem perpajakan yang berlaku di Indonesia. Pengetahuan perpajakan yakni kondisi ketika wajib pajak telah mengetahui dan memahami seluruh peraturan yang tertuang dalam undang-undang perpajakan yang berlaku serta tata cara perpajakan yang telah ditetapkan, yang kemudian dapat diterapkan ketika melaksanakan kewajiban perpajakannya (Yulia et al., 2020). Rahayu (2017) menyebutkan bahwa pengetahuan perpajakan dan kepatuhan membayar pajak memiliki hubungan yang searah dan signifikan. Lain hal dalam riset Hardiningsih \& Yulianawati (2011) yang menyebutkan tidak ada hubungan dan pengaruhnya antara pengetahuan perpajakan terhadap kemauan seseorang untuk membayar pajak.

Faktor lainnya yang diduga berpengaruh terhadap kepatuhan untuk membayar pajak yaitu kesadaran yang ada didalam diri wajib pajak. Menurut (Riadita \& Saryadi, 2019) hingga saat ini, mayoritas wajib pajak di Indonesia memiliki anggapan yang buruk terhadap penarikan pajak yang diselenggarakan oleh pemerintah. Wajib pajak menganggap bahwa pajak ialah beban dan khawatir pembayaran pajak disalahgunakan oleh pihak terkait. Padahal sejatinya pajak adalah sebuah kewajiban agar dilaksanakan oleh wajib pajak guna meningkatkan serta meratakan pembangunan yang diselenggarakan oleh Negara. Wajib pajak yang memiliki kesadaran yang rendah cenderung dengan mudah mengabaikan kewajiban perpajaknya, bahkan tidak sulit bagi mereka untuk melanggar peraturan terkait perpajakan. Disebutkan oleh Marcori (2018) kesadaran wajib pajak merupakan sebuah bentuk perilaku yang tercermin didalam diri individu yang menunjukkan sikap dalam mentaati peraturan terkait pajak baik secara individu maupun badan. Risetnya menyebutkan bahwa terdapat hubungan searah pada kesadaran serta kepatuhan wajib pajak dalam memenuhi segala kewajibannya di bidang perpajakan. Semakin tingi kesadaran yang ada didalam diri wajib pajak, maka kepatuhannya untuk melaksanakan kewajiban perpajakan juga meningkat. Kesadaran dalam diri wajib pajak akan muncul apabila terdapat sikap didalam dirinya yang menjunjung tinggi etika, norma hukum dan memiliki rasa tanggung jawab untuk patuh dan taat terhadap setiap peraturan terkait perpajakan, sehingga dapat menjadi warga Negara yang baik. Tidak sependapat dengan penelitian ini, Nugroho (2016) menyatakan bahwa antara kesadaran wajib pajak dengan pemenuhan kewajiban membayar

\footnotetext{
Pengaruh Pengetahuan Perpajakan, Kualitas Pelayanan Dan Kesadaran Wajib Pajak Terhadap Kepatuhan Wajib PajakUMKM Surabaya, Chandra Pitaloka Puspodewanti dan Susanti
} 
pajak tidak ada pengaruhnya. Meskipun wajib pajak memiliki kesadaran pajak yang tinggi, belum tentu mereka dapat melaksanakan tanggung jawab untuk memenuhi segala kewajiban perpajakannya. Kesadaran yang terdapat didalam diri wajib pajak, dapat diukur melalui dua indikator yaitu kedisiplinan wajib pajak serta kemauan membayar pajak (Suendi, 2011).

Selain faktor yang terdapat didalam diri wajib pajak, faktor lingkungan luar juga dapat berpengaruh. Salah satunya adalah faktor kualitas pelayanan petugas pajak yang mana dapat mempengaruhi bagaimana wajib pajak menyelesaikan kewajiban pajaknya. Upaya yang dapat dilakukan oleh pemerintah melalui DJP yaitu dengan meningkatkan mutu pelayanan yang diberikan kepada wajib pajak saat melaksanakan segala transaksi pajak. Kualitas pelayanan merupakan faktor yang kemungkinan besar dapat mendorong tingkat kepatuhan wajib pajak. Didalam sektor perpajakan, kualitas pelayanan ini merujuk pada setiap kegiatan pelayanan yang dilakukan petugas pajak untuk diberikan kepada seluruh wajib pajak yang akan melaksanakan kewajibannya di bidang perpajakan. Dengan memberikan pelayanan yang terbaik, maka dapat memberikan kesan yang baik serta rasa puas dan nyaman kepada wajib pajak saat melakukan transaksi perpajakan. Mutu pelayanan yang diberikan, dapat menjadi dasar wajib pajak untuk memenuhi segala kewajibannya di bidang perpajakan. Sejalan dengan riset (Komala et al., 2019) di KPP Madya Malang menyatakan bahwa kualitas pelayanan dan kepatuhan membayar pajak memiliki pengaruh yang positif dan signifikan. Namun tidak sejalan dengan hasil riset oleh Ester et al., (2017), menyebutkan bahwa kualitas pelayanan kantor pajak tidak memberikan pengaruh terhadap kepatuhan membayar pajak oleh wajib pajak. Menurutnya petugas pajak wajib memberikan pelayanannya yang terbaik, sebab seluruh wajib pajak berhak untuk menerima kualitas pelayanan yang maksimal. Sehingga kualitas pelayanan yang diberikan petugas pajak tidak memberikan pengaruhnya yang signifikan pada kepatuhan wajib pajak untuk melaksanakan kewajibannya. Menurut Ariyanto (2019) kualitas pelayanan ialah mutu pelayanan y ang dapat dirasakan oleh wajib pajak saat petugas pajak melayaninya saat melaksanakan kewajibannya di bidang perpajakan. Kualitas pelayanan ini kemudian dapat memberikan kesan kepada setiap wajib pajak, lalu akan menentukan bagaimana keputusan wajib pajak tersebut untuk melaksanakan kembali kewajiban perpajakannya dimasa yang akan datang. Menurut Najib \& Rusydi (2013) tujuan kualitas pelayanan ini adalah memberikan rasa kenyamanan, keamanan serta kepastian yang tinggi bagi wajib pajak dalam melaksanakan pemenuhan hak dan kewajibannya di bidang perpajakan. Adapun ketanggapan, keandalan, bukti fisik, jaminan, serta empati merupakan lima indikator yang dapat digunakan untuk mengukur tinggi dan rendahnya kualitas pelayanan yang dilakukan petugas pajak.

Terdapat banyak sekali pajak yang ditetapkan oleh pemerintah guna meningkatkan pendapatan Negara. Salah satunya yaitu pelaku UMKM yang diwajibkan agar terdaftar sebagai wajib pajak serta dibebankan pajak penghasilan atas penghasilan yang telah diterimanya. Pelaku UMKM atau Usaha Mikro Kecil Menengah merupakan wajib pajak orang pribadi dengan melakukan pekerjaan bebas dan saat ini pertumbuhannya semakin meningkat (Sari, 2018). Saat ini UMKM merupakan kegiatan usaha yang berkembang dan mendominasi pertumbuhan perekonomian Indonesia. Hingga tahun 2018 tercatat pelaku UMKM yang tersebar di seluruh Indonesia berjumlah 64.194.057 unit. Jumlah tersebut terbagi atas pelaku usaha mikro sebesar 63.350.222, usaha kecil sebesar 783.132 dan usaha menengah sebesar 26.043 (www.depkop.go.id). Pertumbuhan UMKM diharapkan dapat meningkatkan penerimaan pajak yang kemudian pembangunan Negara dapat terlaksana secara merata, melalui penarikan PPh Pasal 4 ayat 2 bagi pelaku UMKM. Kementrian Koperasi dan UMKM menyatakan bahwa dari seluruh jumlah pelaku UMKM di Indonesia, hanya terdapat sekitar 2,3\% pelaku UMKM yang tercatat sebagai wajib pajak dengan memiliki identitas pajak berupa NPWP. Hal ini menunjukkan bahwa penerimaan pajak yang bersumber dari pelaku UMKM cenderung tidak stabil.

Pengaruh Pengetahuan Perpajakan, Kualitas Pelayanan Dan Kesadaran Wajib Pajak Terhadap Kepatuhan Wajib PajakUMKM Surabaya, 
Surabaya merupakan kota dengan tingkat pertumbuhan usaha yang pesat. Dapat dikatakan Surabaya adalah salah satu pusat pertumbuhan di Negara Indonesia. Banyak para pelaku usaha yang mengembangkan bisnisnya di kota ini, hal tersebut menjadikan kota Surabaya sebagai kota yang memiliki pelaku UMKM terbanyak kelima di provinsi Jawa Timur setelah Sumenep, Banyuwangi, Malang dan Jember (www.diskopukm.jatimprov.go.id). Dengan demikian, diharapkan kota Surabaya dapat menjadi salah satu kota dengan tingkat penerimaan pajak yang tinggi, sehingga dapat turut menyumbang kas Negara untuk pembiayaan pembangunan nasional.

KPP Pratama Surabaya Wonocolo, salah satu KPP yang ada di Surabaya yang wilayah kerjanya terbilang cukup luas, meliputi kecamatan Wonocolo, Wonokromo, Gayungan, serta Jambangan. Tercatat jumlah pelaku UMKM yang terdaftar pada KPP Surabaya Wonocolo ini berjumlah 4430 wajib pajak. Adapun besaran pajak penghasilan yang bersumber dari pelaku UMKM yang telah diperoleh KPP Surabaya Wonocolo sebagai berikut :

Tabel 2.

Data Penerimaan Pajak Penghasilan Pelaku UMKM KPP Surabaya Wonocolo

\begin{tabular}{cc}
\hline Tahun & Penerimaan \\
\hline 2017 & $\operatorname{Rp} 29.840 .494 .721$ \\
2018 & $\operatorname{Rp} 28.492 .435 .117$ \\
2019 & $\mathrm{RP} 21.974 .079 .212$
\end{tabular}

Sumber: KPP Sura baya Wonocolo, 2021

Dari data tersebut, mengindikasikan bahwa kepatuhan wajib pajak pelaku kegiatan UMKM dikatakan masih rendah, sebab dari tahun 2017 hingga 2019 penerimaannya cenderung menurun. Padahal, meningkatnya pelaku UMKM disurabaya diharapkan pula dapat meningkatkan penerimaan pajaknya. Sayangnya, banyak pelaku UMKM yang sebisa mungkin menghindari untuk membayar pajak atas penghasilan yang diterima karena menganggap pajak sebagai beban. Para pelaku UMKM masih menilai bahwa membayar pajak hanya akan merugikan usahanya. Padahal, peranan UMKM dalam meningkatkan perekonomian serta proses perencanaan suatu kebijakan pemerintah dibidang perpajakan amat dibutuhkan. Sehingga kepatuhan wajib pajak pelaku kegiatan UMKM dalam menjalankan tanggung jawab untuk melaksanakan kewajiban pajaknya sangat diharapkan (Fuadi \& Mangoting, 2012). Melalui Direktorat Jenderal Pajak, pemerintah telah melakukan penurunan untuk PPh Final bagi pelaku UMKM tertuang dalam PP no. 23 Tahun 2018, menyebutkan bahwa tarif PPh final yang berlaku bagi pelaku UMKM adalah sebesar 0,5\% dari peredaran brutonya, yang sebelumnya adalah $1 \%$. Hal ini dimaksutkan agar pelaku UMKM dapat meningkatkan kepatuhannya untuk melaksanakan kewajiban di bidang perpajakan dengan beban yang lebih ringan sesuai dengan ketentuan dan undang-undang yang telah ditetapkan.

Berdasarkan permasalahan yang ditemukan dan penjelasan yang telah dipaparkan, peneliti mengajukan hipotesis, antara lain : H1). Secara parsial, terdapat pengaruh secara signifikan antara pengetahuan perpajakan dan kepatuhan membayar pajak pelaku UMKM Kota Surabaya. H2). Secara parsial, terdapat pengaruh secara signifikan antara kualitas pelayanan dan kepatuhan membayar pajak pelaku UMKM Kota. H3) Secara parsial, terdapat pengaruh secara signifikan antara kesadaran wajib pajak dan kepatuhan membayar pajak pelaku UMKM Kota Surabaya.

Pengaruh Pengetahuan Perpajakan, Kualitas Pelayanan Dan Kesadaran Wajib Pajak Terhadap Kepatuhan Wajib PajakUMKM Surabaya, 


\section{METODE PENELITIAN}

Riset ini dilakukan agar dapat melihat apakah antara pengetahuan perpajakan, kualitas layanan, serta kesadaran wajib pajak pada kepatuhan membayar pajak khususnya wajib pajak yang melakukan kegiatan UMKM di kota Surabaya memiliki pengaruh secara signifikan. Riset ini berjenis kuantitatif deskriptif dengan melihat hubungan antar variable serta hubungan sebab-akibat. Variable independent dari penelitian ini antara lain pengetahuan perpajakan (X1), kualitas layanan (X2), dan kesadaran wajib pajak (X3). Sedangkan untuk variable dependen yaitu kepatuhan membayar pajak (Y). Berikut rancangan penelitian antar variabel dependen dengan variabel independen :

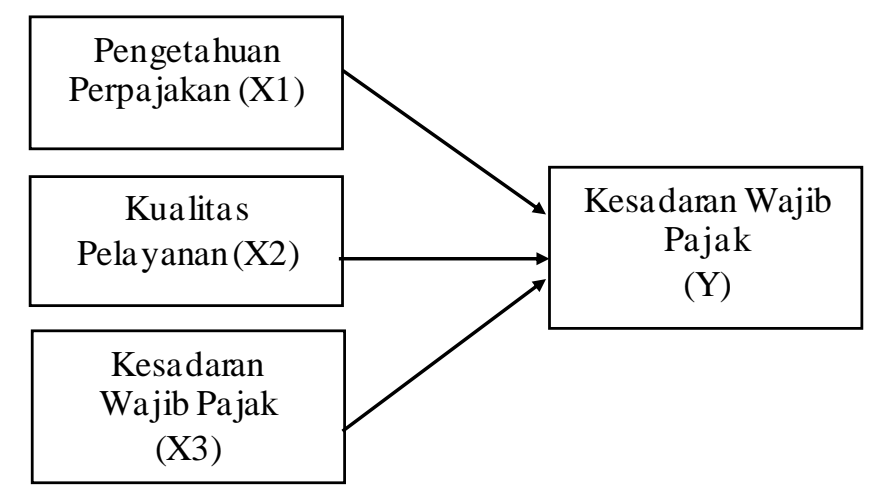

Gambar 1.

Rancangan Penelitian

Teknik pengambilan sample pada riset ini Accidental Sampling. Artinya setiap wajib pajak yang ditemui secara tidak sengaja dan sesuai dengan kriteria penelitian ini dapat dijadikan sample. Populasi adalah pelaku UMKM yang telah terdaftar di KPP Pratama Surabaya Wonocolo sebanyak 4430 WP. Menurut teori Roscoe dalam buku Sugiyono (2017) penelitian yang menggunakan analisis multivariate jumlah sample nya adalah 10x lipat dari seluruh jumlah variabel dalam penelitian. Dengan demikian jumlah sample yang diambil untuk melakukan riset ini adalah sebanyak 40 wajib pajak. Seluruh variabel baik dependen maupun independent berjumlah 4 dan dikalikan 10, dan mendapat hasil 40.

Data primer yang diperoleh untuk melakukan riset ini adalah melalui instrument penelitian berupa kuisioner sebagai alat pengumpulnya. Kuisioner berisikan daftar pertanyaan terstruktur yang ditujukan langsung kepada responeden terpilih. Pada variabel pengetahuan perpajakan instrument penelitian berupa tes yang kemudian akan diukur menggunakan Skala Guttman. Apabila jawabannya benar maka akan mendapat skor 1 dan 0 apabila jawabannya salah. Sedangkan untuk variabel lainnya, kuisioner menggunakan Skala Likert 1-4 poin. Pada variable X1 (Pengetahuan Perpajakan), X3 (Kesadaran Wajib Pajak) serta Y (Kepatuhan Wajib Pajak) daftar pertanyaan dalam kuesioner merujuk pada penelitian yang dilakukan oleh Adi (2018). Dan untuk variable kualitas pelayanan (X2) daftar pertanyaan dalam kuesioner merujuk penelitian Ariyanto (2019). Sedangkan untuk data sekunder didapatkan dari Dinas Koperasi dan UMKM Surabaya serta KPP Pratama Surabaya Wonocolo untuk mengetahui data pelaku UMKM di Kota Surabaya.

Teknik analisis data merupakan cara atau proses untuk menyedederhanakan data agar mudah dibaca dan diinterprestasikan kedalam bentuk yang lebih sederhana. Riset ini, menggunakan

Pengaruh Pengetahuan Perpajakan, Kualitas Pelayanan Dan Kesadaran Wajib Pajak Terhadap Kepatuhan Wajib PajakUMKM Surabaya, 
pendekatan kuantitatif serta metode analisis dimana perhitungannya dilakukan melalui software SPSS. Analisis data ini ditujukan untuk menjawab dan membuktikan hipotesis yang sebelumnya telah disebutkan. Yang mana setelah data terkumpul, proses yang dilalui antara lain uji kelayakan instrument penelitian, uji asumsi klasik, kemudian dilakukan uji hipotesis serta analisis regresi linier berganda.

\section{HASIL DAN PEMBAHASAN}

Melalui penyebaran kuesioner secara langsung yang dilakukan oleh peneliti di KPP Pratama Surabaya Wonocolo diketahui bahwa responden adalah 21 orang berjenis kelamin perempuan dan sisanya sebanyak 19 adalah laki-laki. Reponden terbanyak adalah pelaku kegiatan UMKM yang memiliki usaha dibidang kuliner atau makanan dan minuman yaitu sebesar $40 \%$ yang mayoritas pendidikan terakhirnya adalah SMU/Sederajat sebayak 55\%.

Hasil uji kelayakan instrument dilakukan melalui uji validitas dan reabilitas. Pada uji validitas menggunakan pendekatan person correlation, artinya setiap butir pernyataan dapat dinyatakan valid ketika $r$ tabel $<r$ hitung. Diketahui dalam riset ini $r$ tabel adalah sebesar 0,361. Dan nilai $r$ hitung yang diperoleh melalui perhitungan menggunakan SPSS 25 seluruh item pernyataan pada variabel independen dan dependen adalah diatas 0,361 sehingga 45 butir pernyataan adalah valid. Selanjutnya untuk uji reabilitas menggunakan pendekatan cronbach alpha, dimana ketika nilai koefisien cronbach alpha $>0,60$ maka instrument dinyatakan reliable. Pada variabel X1 (pengetahuan perpajakan), X2 (kualitas pelayanan), X3 (kesadaran wajib pajak), serta Y (kepatuhan wajib pajak) berturut-turut memperoleh nilai cronbach alpha yaitu 0,$634 ; 0,847 ; 0,720 ; 0,845$. Demikian dapat dinyatakan bahwa seluruh butir pernyataan tiap variabel yang diangkat dalam riset ini adalah reliable dan layak untuk disebarkan kepada responden.

Tabel 3.

\section{Hasil Uji Normalitas}

One-Sample Kolmogorov-Smirnov Test

\begin{tabular}{llr}
\hline & & \multicolumn{2}{c}{$\begin{array}{c}\text { Understandardized } \\
\text { Residual }\end{array}$} \\
\hline $\mathrm{N}$ & & 40 \\
NormalParameters ${ }^{\mathrm{a}, \mathrm{b}}$ & Mean &, 0000000 \\
& Std. Deviation & 2,02343652 \\
Most Extreme Differences & Absolute &, 117 \\
& Positive &, 117 \\
& Negative &,- 067 \\
Test Statistic & &, 117 \\
Asymp. Sig. (2-tailed) & &, $179^{c}$ \\
\hline Sumber: Datadiolan, 2021 & &
\end{tabular}

Pengaruh Pengetahuan Perpajakan, Kualitas Pelayanan Dan Kesadaran Wajib Pajak Terhadap Kepatuhan Wajib PajakUMKM Surabaya, 
Tabel 4.

Hasil Uji Multikolinearitas

Coefficients $^{\mathbf{a}}$

\begin{tabular}{llll}
\hline & & \multicolumn{2}{c}{ Collinearity } \\
Statistics & \\
Model & & Tolerance & VIF \\
\hline 1 & (Constant) & & 3,449 \\
& X1 & 0,290 & 1,955 \\
& X2 & 0,512 & 3,357 \\
& X3 & 0,298 & \\
& & & \\
&
\end{tabular}

Sumber: Data diolah, 2021

Hasil uji normalitas disajikan pada tabel 3. One-sample Kolmogorov-Smirnov merupakan teknik yang digunakan dalam riset ini untuk menguji normalitas data, dan mendapat hasil sebesar 0,179 . Sehingga dinyatakan data yang digunakan pada riset ini memiliki data dengan distribusi yang normal. Sebab nilai signifikansi yang diperolah berada diatas 0,05 sehingga riset ini layak untuk menggunakan model regresi.

Pada uji multikolenearitas mendapatkan hasil bahwa data pada tiap-tiap variabel independen yang digunakan tidak menunjukkan terjadinya multikolinearitas. Hasil uji multikolinearitas dapat diketahui melalui nilai collinearity tolerance serta VIF (Variance Inflance Factor). Dikatakan tidak terjadi multikolinearitas karena seluruh varibelnya memiliki collinearity tolerance > 0,10 serta VIF < 10,00 .

Tabel 5.

Hasil Uji Heteroskedastisitas

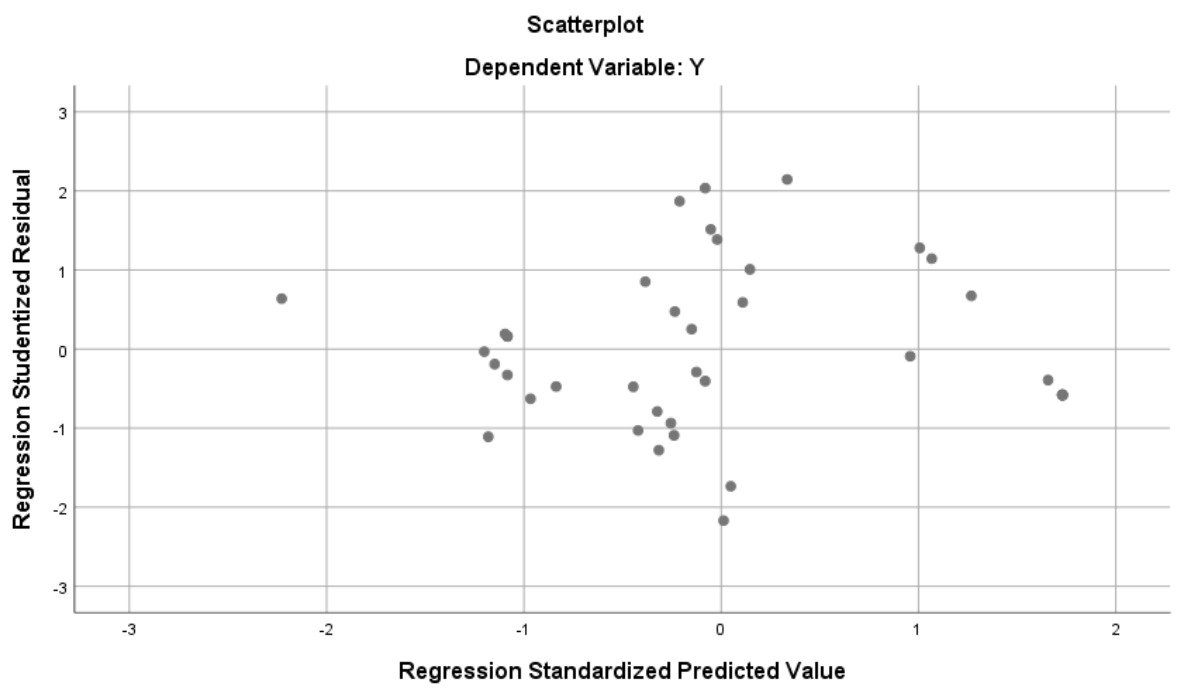

Sumber: Data diolah, 2021

Pengaruh Pengetahuan Perpajakan, Kualitas Pelayanan Dan Kesadaran Wajib Pajak Terhadap Kepatuhan Wajib PajakUMKM Surabaya, 
Melalui tabel 5 disajikan hasil uji heteroskedastisitas. Pada grafik tersebut menjelaskan bahwa data yang diolah tidak terjadi gejala heteroskedastisitas. Sebab terlihat pada grafik scatter plot tersebut titik-titik data tidak berkumpul menjadi satu pada bagian atas ataupun bawah saja, melainkan menyebar diantara angka 0 dan tidak terbentuk pola. Oleh sebab itu data yang ada dalam penelitian ini tidak mengindikasikan terjadinya gelaja heterokedastisitas.

Tabel 6.

Hasil Uji Statistik F

\begin{tabular}{llrrrrr}
\multicolumn{8}{c}{ ANOVA $^{\mathbf{a}}$} & & \\
\hline Model & & Sum of Squares & Df & Mean Square & F & \multicolumn{2}{c}{ Sig. } \\
\hline 1 & Regression & 1033,822 & 3 & 344,607 & 7,693 &, $000^{\mathbf{b}}$ \\
& Residual & 159,678 & 36 & 4,435 & & \\
& Total & 1193,500 & 39 & & & \\
& & & & & & \\
\hline
\end{tabular}

Sumber: Data diolah, 2021

Uji ststistik F dilakukan untuk melihat apakah model penelitian layak serta mengetahui bagaimana pengaruh variabel pengetahuan perpajakan, kualitas pelayanan, dan kesadaran wajib pajak terhadap kepatuhan wajib pajak secara simultan. Dengan melihat hasil signifikansi serta F hitung diketahui bahwa nilai signifikansi pada riset ini adalah 0,000 lebih kecil dibandingkan taraf signifikansi yaitu 0,05. Sehingga model pada riset ini fit dan layak digunakan sebagai penelitian. Sedangkan F hitung yang didapatkan adalah sebesar 7,693 lebih besar dibandingkan F tabel dalam model penelitian ini. Artinya, seluruh variabel dependen dalam riset ini secara simultan mempengaruhi variabel independen nya.

Setelah dilakukan uji $\mathrm{F}$, untuk melihat apakah secara parsial antara setiap variabel independen (pengetahuan perpajakan, kualitas pelayanan, dan kesadaran wajib pajak) terhadap variabel dependen (kepatuhan wajib pajak) memiliki pengaruh secara signifikan maka dilakukan uji T. Dimana pada uji $\mathrm{T}$ dalam penelitian ini menghasilkan persamaan regresi :

$$
\mathrm{Y}=2,043+3,410_{(\mathrm{X} 1)}+0,063_{(\mathrm{X} 2)}+0,542_{(\mathrm{X} 3)}
$$

Sehubungan dengan persamaan regresi yang telah diperoleh, dijelaskan beberapa hal, antara lain : (1) Nilai konstanta dari persamaan tersebut adalah sebesar 2,043. Diasumsikan apabila X1 (pengetahuan perpajakan), X2 (kualitas pelayanan), dan X3 (kesadaran wajib pajak) nilainya adalah 0, diprediksi nilai untuk kepatuhan wajib pajak (Y) adalah sebesar 2,043. (2) Pada variabel X1 (pengetahuan perpajakan) nilai koefisiennya adalah $+3,410$. Artinya jika nilai pengetahuan perpajakan mengalami peningkatan 1 , maka kepatuhan wajib pajak juga dapat mengalami peningkatan $+3,410$. Pada koefisien tersebut nilainya adalah positif (+) sehingga dapat diartikan terdapat hubungan yang sejalan antara pengetahuan perpajakan dengan kepatuhan wajib pajak untuk melaksanakan kewajiban perpajakannya. (3) Koefisien pada variabel X2 (kualitas pelayanan) adalah $+0,063$. Dapat diasumsikan, ketika nilai kualitas pelayanan mengalami peningkatan 1 , kepatuhan wajib pajak juga dapat mengalami peningkatan $+0,063$. Pada koefisien tersebut nilainya adalah positif $(+)$ sehingga dapat diartikan terdapat hubungan yang searah pada kualitas pelayanan petugas pajak meningkat dan

Pengaruh Pengetahuan Perpajakan, Kualitas Pelayanan Dan Kesadaran Wajib Pajak Terhadap Kepatuhan Wajib PajakUMKM Surabaya, 
kepatuhan wajib pajak untuk melaksanakan kewajiban perpajakannya. (4) Koefisien pada variabel X3 (kesadaran wajib pajak) yaitu sebesar $+0,542$. Hal tersebut dapat diartikan ketika kesadaran wajib pajak mengalami peningkatan 1 , kepatuhan wajib pajak akan mengalami peningkatan pula sebesar $+0,542$. Dan koefisien pada nilai tersebut adalah positif (+) sehingga terdapat hubungan yang sejalan antara kesadaran wajib pajak serta kepatuhan wajib pajak untuk melaksanakan kewajiban perpajakannya.

\section{Tabel 7.}

Hasil Uji T

\begin{tabular}{|c|c|c|c|c|c|c|}
\hline \multicolumn{7}{|c|}{ Coefficients $^{\mathrm{a}}$} \\
\hline \multirow[b]{2}{*}{ Mod } & & \multicolumn{2}{|c|}{ Understandardized Coefficients } & \multirow{2}{*}{$\begin{array}{c}\text { Standardized } \\
\text { Coefficients } \\
\text { Beta }\end{array}$} & \multirow[b]{2}{*}{$\mathrm{T}$} & \multirow[b]{2}{*}{ Sig. } \\
\hline & & $\mathrm{B}$ & Std.Error & & & \\
\hline \multirow[t]{4}{*}{1} & (Constant) & 2,043 & 2,956 & & 2,691 & ,494 \\
\hline & $\mathrm{X} 1$ & 3,410 & ,591 & 653 & 5,769 & ,000 \\
\hline & $\mathrm{X} 2$ & ,063 & ,070 & ,076 & 892 & ,378 \\
\hline & $\mathrm{X} 3$ & ,237 & 237 & ,256 & 2,290 & ,028 \\
\hline
\end{tabular}

Sumber: Data diolah, 2021

Pada tabel 6 telah diketahui hasil uji parsial dan menunjukkan bahwa pada variabel X1 nilai signifikansinya $0,000<0,05$ dengan $t$ hitung 5,69. Sehingga dinyatakan bahwa secara parsial pengetahuan perpajakan (X1) memberikan pengaruh pada kepatuhan wajib pajak (Y) secara signifikan. Dengan demikian H1 diterima. Hasil ini didukung oleh Mir'atusholihah et al., (2014) dalam risetnya menyebutkan bahwa antara pengetahuan perpajakan yang dimiliki oleh setiap wajib pajak dan kepatuhan wajib pajak untuk menuntaskan segala kewajiban perpajakannya memiliki hubungan yang searah. Sejalan dengan riset oleh Hartini \& Sopian (2018) yang menyebutkan bahwa kepatuhan wajib pajak untuk menjalankan kewajibannya dalam membayar pajak dipengaruhi oleh pengetahuan pajak yang dimilikinya. Pengetahuan perpajakan merupakan dasar utama yang dapat menentukan bagaimana sikap wajib pajak unutuk menjalankan kewajiban perpajakannya. Sebab sistem perpajakan yang dianut oleh Indonesia adalah self assessment system. Tanpa memiliki pengetahuan yang baik, wajib pajak tidak dapat mengetahui bagaimana tata cara untuk menyelesaikan kewajiaban dalam bidang perpajakan dan tidak dapat menentukan perilaku yang tepat serta dapat menimbulkan ketidakpatuhan baik secara disengaja maupun tanpa sengaja. Demikian pengetahauan perpajakan diperlukan agar setiap wajib pajak dapat patuh dan taat dalam menjalankan dan menyelesaikan seluruh kewajibannya.

Uji parsial pada variabel X2 (kualitas pelayanan) menunjukkan nilai signifikansi 0,378 yang mana hasil tersebut lebih tinggi dibanding taraf signifikansi yaitu $5 \%$ atau 0,05 . Artinya, hasil dalam riset menunjukkan secara parsial kualitas pelayanan (X2) pada tingkat kepatuhan wajib pajak (Y) dalam memenuhi kewajiban perpajakannya tidak memberikan pengaruhnya secara signifikan. Berbeda dengan riset sebelumnya yang telah dilakukan oleh Raharjo et al., (2020) bahwa kualitas pelayanan akan mempengaruhi kepatuhan wajib pajak dalam memenuhi kewajibannya secara signifikan. Sehingga $\mathrm{H} 2$ ditolak. Namun hasil dalam penelitian ini didukung oleh hasil riset Bahri et al., (2018) yang juga mendapatkan hasil, bahwa dalam memenuhi segala kewajiban seseorang di bidang perpajakan, kualitas pelayanan petugas bukanlah hal yang utama.

Pengaruh Pengetahuan Perpajakan, Kualitas Pelayanan Dan Kesadaran Wajib Pajak Terhadap Kepatuhan Wajib PajakUMKM Surabaya, 
Sebab, layanan yang baik merupakan sebuah keharusan untuk diberikan kepada setiap wajib pajak yang melaksanakan kegiatannya di kantor pajak oleh para petugas pajak. apabila dikaitkan dengan penelitian yang telah dilakukan di KPP Pratama Surabaya Wonocolo, kualitas pelayanan yang diberikan oleh petugas pajak memang kurang maksimal. Dikarenakan adanya pandemic covid-19 dimana adanya pembatasan kegiatan hingga beberapa petugas pajak diharuskan untuk work from home agar tidak menimbulkan keramaian. Sehingga menyebabkan pelayanan yang diberikan oleh petugas bersifat terbatas baik waktu maupun tenaga. Hal tersebut yang kemudian menciptakan kesan yang kurang baik bagi para wajib pajak yang sedang melakukan kegiatan dikantor pajak. Padahal petugas pajak di KPP Pratama Surabaya Wonocolo telah melakukan pelayanan yang tergolong cukup baik. Para petugas bertugas sesuai dengan standart yang berlaku, serta banyak membantu para wajib pajak apabila menemui kesulitan dalam pelaporan pajaknya. Namun waktu yang singkat sehingga terjadi pembatasan kegiatan.

Variabel X3 (kesadaran wajib pajak) mendapat nilai signifikansi 0,028. Angka tersebut menunjukkan nilai dibawah taraf signifikasi atau 0,05 serta t hitung sebesar 2,290. Dengan demikian, dapat dikatakan kesadaran wajib pajak (X3) secara parsial memberikan pengaruh yang signifikan pada kepatuhan wajib pajak (Y) untuk menjalankan kewajiban perpajakannya. Maka H3 diterima. Mendukung hasil riset Adinata (2015) yang juga mendapatkan hasil kesadaran wajib pajak dengan kepatuhan wajib pajak untuk memenuhi kewajibannya di bidang perpajakan memiliki hubungan yang searah dan signifikan. Selain itu Ramadhan (2017) juga menyebutkan bahwa kepatuhan wajib pajak pelaku UKM dalam membayar pajak penghasilannya dipengaruhi secara signifikan oleh faktor kesadaran wajib pajak tersebut.

Berbeda dengan riset sebelumnya oleh Yusmaniarti, Setiorini \& Puja, (2020) yang menerangkan bahwa tidak ada pengaruh yang signifikan pada kesadaran wajib pajak dengan kepatuhan wajib pajak. Banyak wajib pajak yang sadar bahwa salah satu penerimaan terbesar Negara yang dapat digunakan sebagai pembiayaan untuk meningkatkan kemakmuran Negara secara merata adalah bersumber dari pajak, namun hal tersebut tidak cukup untuk membuat wajib pajak mematuhi segala peraturan terkait segala kewajiban perpajaknnya. Sebab tidak sedikit wajib pajak menganggap bahwa pajak yang telah dibayarkan akan disalahgunakan oleh petugas yang berwewenang. Menurut Yusmaniarti, Setiorini \& Puja, (2020) untuk dapat meningkatkan kesadaran wajib pajak, perlu adanya peran aparatur pajak. Aparatur pajak dapat memberikan sosialiasasi kepada wajib pajak tentang kepentingan membayar pajak. Sebab tanpa adanya kesadaran wajib pajak untuk melaksanakan kewajibannya, hal tersebut dapat menjadi masalah besar bagi kehidupan Negara karena kurang maksimalnya pendapatan dalam sektor perpajakan. Berdasarkan penelitian yang dilakukan di KPP Pratama Surabaya Wonocolo, para pelaku UMKM sudah memiliki kesadaran yang cukup baik untuk melaksanakan kewajibannya di bidang perpajakan. Terbukti dari pendapatan pajak oleh pelaku usaha yang setiap tahun selalu meningkat.

Dari hasil analisis koefisien determinasi, didapatkan Adjusted R Square 0,855. Berkaitan hal tersebut, pengetahuan wajib pajak, kualitas pelayanan petugas pajak, serta kesadaran dalam diri wajib pajak memberikan pengaruh terhadap kepatuhan wajib pajak secara bersama-sama sebesar $85,5 \%$. Sedangkan 14,5\% lainnya tingkat kepatuhan wajib pajak dapat dipengaruhi oleh faktor yang tidak termasuk dalam variabel riset ini.

Pengaruh Pengetahuan Perpajakan, Kualitas Pelayanan Dan Kesadaran Wajib Pajak Terhadap Kepatuhan Wajib PajakUMKM Surabaya, 
Tabel 8.

Hasil Analisis Koefisien Determinasi

Model Summary

\begin{tabular}{lrrrrr}
\hline Model & $\mathrm{R}$ & $\mathrm{R}$ Square & $\begin{array}{c}\text { Adjusted } \mathrm{R} \\
\text { Square }\end{array}$ & $\begin{array}{c}\text { Std. Error of the } \\
\text { Estimate }\end{array}$ & Durbin-Watson \\
\hline 1 &, $391^{\mathrm{a}}$ &, 866 &, 855 & 2,106 & 2,350 \\
\hline Sumber: Data diolah, 2021 & & & &
\end{tabular}

\section{SIMPULAN DAN SARAN}

Dari hasil dan pembahasan penelitian yang telah dijabarkan diatas, peneliti menyimpulkan beberapa hal, antara lain : 1) secara parsial antara pengetahuan perpajakan dengan kepatuhan wajib pajak, khususnya para pelaku UMKM di Kota Surabaya memiliki pengaruh yang positif dan signifikan. Sehingga H1 diterima. 2) secara parsial antara kualitas pelayanan dengan kepatuhan wajib pajak, khususnya para pelaku UMKM di Kota Surabaya tidak terdapat pengatuh yang signifikan. Sehingga $\mathrm{H} 2$ ditolak. 3) secara parsial antara kesadaran wajib pajak dengan kepatuhan wajib pajak, khususnya para pelaku UMKM di Kota Surabaya memiliki pengaruh yang positif dan signifikan. Sehingga H3 diterima.

Berkaitan dengan seluruh penjelasan, maka peneliti memberikan saran antara lain yaitu bagi KPP Pratama Surabaya Wonocolo untuk dapat melakukan kegiatan sosialisasi perpajakan teruma dengan sasaran para pelau UMKM sehingga pengetahuan serta kesadaran pelaku UMKM untuk membayar pajak akan meningkat. Dengan demikian, dapat meningkatkan pula kepatuhan bagi para pelaku UMKM dalam membayar pajak atas penghasilannya ang diterima. Bagi wajib pajak, untuk dapat memanfaatkan fasilitas online yang telah disediakan oleh KPP Pratama Surabaya Wonocolo dengan hal tersebut maka wajib pajak yang akan melaporkan SPT dapat melakukannya dirumah. Sehingga tidak menimbulkan keramaian di kantor pajak dan tidak perlu antre. Saran untuk penelitian selanjutnya yaitu dapat memperluas populasi serta menambah jumlah sample, dengan demikian dapat memperoleh hasil yang lebih representatif. Selain itu dapat pula menambahkan variabel yang tidak diangkat dalam penelitian ini, sebab diketahui hasil dalam penelitian masih terdapat $14,5 \%$ faktor yang kemungkinan besar akan memberikan pengaruh untuk patuh dalam melaksanakan kewajiban serta tanggung jawab dalam pembayaran tagihan pajak.

\section{REFERENSI}

Adi, T. W. (2018). Pengaruh Pengetahuan Perpajakan, Sanksi Perpajakan, dan Kesadaran Waj ib Pajak B adan Pada KPP Pratama Cilacap Tahun 2018. SKRIPSI.

Adina ta, A. (2015). Pengaruh Keadaran Membayar Pajak, Pemahaman Tentang Pajak, Sanksi Perpa jakan, dan Kualitas Pelayanan Terhadap Kepatuhan Wajib Pajak (Studi Pa da Kantor Pela yanan Pajak Pratam a Tampan Pekanbaru). Jom FEKON, 2(2).1-14.

Ariyanto, D. (2019). Pengaruh Persepsi Tarif Pajak, Kualitas Pelayanan, dan Pengetahuan Perpajakan Terha dap Kepatuhan Wajib Pajak UMKM. SKRIPSI.

Pengaruh Pengetahuan Perpajakan, Kualitas Pelayanan Dan Kesadaran Wajib Pajak Terhadap Kepatuhan Wajib PajakUMKM Surabaya, 
Bahri, S., Diantimala, Y., \& Majid, M. S. A. (2018). Pengaruh Kualitas Pela yanan Pajak, Pemahaman Peraturan Perpajakan Serta SanksiPerpajakan Terhadap Kepatuhan Wajib Pajak. Jurnal Perspektif Ekonomi Darussalam, 4(2), 318-334.

Ester, K. G., Nangoi, G. B., \& Alexander, S. W. (2017). Pengaruh Kualitas Pelayanan Pajak Dan Pengetahuan Wajib Pajak Terhadap Kepatuhan Wajib Pajak Orang Pribadi Di Kelurahan Kleak Kecamatan Malalayang Kota Manado. GOING CONCERN: JURNAL RISET AKUNTANSI. 12(2). 523-530. https://doi.org/10.32400/gc.12.2.17951.2017

Fuadi, A. O. dan, \& Mangoting, Y. (2012). Pengaruh Kualitas Pelayanan Petugas Pajak, Sanksi Perpajakan dan Biaya Kepatuhan Pajak Terhadap Kepatuhan Wajib Pajak UMKM. ProgramAkuntansi Pajak Program Studi Akuntansi Universitas Kristen Petra ABSTRAK, 1(2), 18-26.

Hardiningsih, P., \& Yulianawati, N. (2011). Faktor-Faktor Yang Mempengaruhi Kemauan Membayar Pajak. Dinamika Keuangan Dan Perbankan, 3(1), 126-142.

Hartini, O. S., \& Sopian, D. (2018). Pengaruh Pengetahuan Perpajakan dan Kesadaran Wajib Pajak Terhadap Kepatuhan Wajib Pajak Orang Priba di. Sains Manajemen Dan Akuntansi, 10(2), 43-56.

Komala, K. C., Suhadak., \& Endang NP, M. G. W. (2019). Pengaruh Kualitas Pelayanan Perpajakan terhadap kepatuhan membayar pajak. Journal of Brawijaya.1-9

Kusuma, K. C. (2016). Pengaruh Kualitas Pelayanan Pajak, Pemahaman Peraturan Perpajakan Serta Sank si Perpajakan Terhadap Kepatuhan Wajib Pajak Orang Pribadi Dalam Membayar Pajak Tahun 2014 (Stu di Ka sus Pada Wajib Pajak yang Terdaftar di Kantor Pelayanan Penyuluhan dan Konsulta. SKRIPSI.

Marcori, F. (2018). Pengaruh Kesadaran Wajib Pajak, Pelayanan Fiskus, dan Sanksi Pajak Terhadap Kepatu han Wajib Pajak Orang Pribadi yang Melakukan Usaha Kecil Menengah (Studi Empiris pada Kantor Pelay anan Penyuluhan dan Konsultasi Perpajakan Kota Sungai Penuh). Jurnal Akuntansi. 4(4), 1 -18. http://jurnal.unpand.ac.id/index.php/AKS/article/view/1171

Mir'atusholihah, Kumadji, S., \& Ismono, B. (2014). Pengaruh pengetahuan perpajakan, ku alit as pelayanan fiskus, dan tarif pajak terhadap kepatuhan wajib pajak (studi pada wajib pajak UMKM di Kantor Pelay anan Pajak Pra tama Malang Uta ra). Jurnal Mahasiswa Perpajakan, 3(1), 1-10.

Najib, D. F., \& Rusydi, M. K. (2013). Analysis Of Factors Affecting Compliance In Individual Ta xpa y ers Pa y Income Tax (Study of KPP Pratama Malang Utara's Individual Tax Payers). Jurnal Ilmiah Mahasiswa Fakultas Ekonomi Dan Bisnis Universitas Brawijaya .7(1), 17-24.

Nugroho, A. (2016). Pengaruh Kesadaran Wajib Pajak dan Pengetahuan Perpajakan Wajib Pajak Terhadap Kepatuhan WPOP dalam Membayar Pajak (Studi Kasus Pada KPP Semarang Candi). Journal Of Accounting. 2(2), 1-13.

Okta viani, R. M., \& Adellina,S. (2016). Kepatuhan Wajib PajakUkm. DinamikaAkuntansi, Ke uangan Dan Perbankan, ISSN: 2302-8556, 5(2), 136-145.

Raharjo, N. K., Majidah, M., \& Kurnia, K. (2020). Pengaruh Pemahaman Peraturan Perpajakan, Tarif Pajak, Dan Kualita s Pelayanan Terhadap Kepatuhan Wajib Pajak (Studi Ka sus pada Wajib Pajak Orang Prib a di Non Karya wan di KPP Prata ma Cibinong Periode2020). E-Jurnal Ekonomi Dan Bisnis Universitas Uda yana, 7, 671-686.https://doi.org/10.24843/eeb.2020.v09.i07.p05

Rahayu, N. (2017). Pengaruh Pengetahuan Perpajakan, Ketegasan Sanksi Pajak, dan Tax Am nesty Terhadap Kepatuhan Wajib Pajak. Akuntansi Dewantara, 1(1).15-30.

Ramadhan,L. Y. (2017). Pengaruh Kesadaran, Moralitas dan Budaya Pajak Terhadap Kepatuhan Pajak (Stu di Pada UKM Siola Kota Surabaya). Equity, $1(2) \quad$ 16-33. http://fe.ubhara.ac.id/ojs/index.php/equity/article/download/411/387

Ria dita, F. A., \& Saryadi. (2019). Pengaruh Kualitas Pelayanan, Kesadaran Wajib Pajak, Dan Pengetahuan Pajak Terhadap Kepatuhan Wajib Pajak (Studi Pada Umkm Yang Terdaftar Di Kpp Pra tama Semarang Sela tan). Jurnal Ilmu Administrasi Bisnis, 8(1), 105-113.

Sa putri, G. L. A. (2019). Pengaruh Persepsi Wajib Pajak Tentang PP No 23 Ta hun 2018, Pemahaman, dan Sanksi Perpajakan Terhadap Kepatuhan Wajib Pajak UMKM (Studi Kasus pada UMKM di Kota Surabaya). Jurnal Ilmu Dan Riset Akuntansi. http://jurnalmahasiswa.stiesia.ac.id/index.php/jira/article/download/2560/2566

Sa ri, R. (2018). Kebijakan Insentif Pajak BagiUsa ha Mikro, Kecil, dan Menengah. Kajian Singkat Terhadap Isu Aktual Dan Strategis.

Siat, C.C., \& Toly, A. A. (2018). Faktor-Faktor Yang Mempengaruhi Kepatuhan Wajib Pajak Dalam Memenuhi Kewajiban Membayar Pajak di Surabaya. Jurnal Riset Akuntansi Dan Bisnis Airlang ga, 3(1 ). 372-395. https://doi.org/10.31093/jraba.v3i1.94

Suendi, E. (2011). Perencanaan Pajak. Salemba Empat.

Sugiyono. (2017). Metode Penelitian Kuantitatif, Kualitatif, dan R\&D.

Pengaruh Pengetahuan Perpajakan, Kualitas Pelayanan Dan Kesadaran Wajib Pajak Terhadap Kepatuhan Wajib PajakUMKM Surabaya,

Chandra Pitaloka Puspodewanti dan Susanti 
Yulia, Y., Wija ya, R. A., Sari, D. P., \& Ada wi, M. (2020). Pengaruh Pengetahuan Perpajakan, Kesadaran Waj ib Pajak, Tingkat Pendidikan, dan Sosialisasi Perpajakan terhadap Kepatuhan Wajib PajakPa da UMKM di Kota Pa dang. JEMSI, 1(4), 305-310. https://doi.org/10.31933/JEMSI

Yusmaniarti, Setiorini, H., \& Puja, H. (2020). Taxpayer Environment Towards The Intention To Pa y Tax es Of SME in Bengkulu. Bilancia : Jurnal Ilmiah Akuntansi, 4(3), 280-288. 